\title{
Study on Barriers to Trade and Current International Trade System Jing $\mathrm{Ma}^{1}$ \\ ${ }^{1}$ Economic and Trade Department, Xijing University, Xi'an, 710123, China
}

\section{Keyword: Barriers to Trade, International Trade System}

Abstract. Barriers to Trade (TBT) is a system, mainly by the technical regulations, it can be divided to: standards and conformity assessment procedures; packaging and labeling requirements; commodity quarantine and inspection requirements; green barriers and IT system constitute barriers

\section{Introduction}

Technical Barriers to Trade (TBT) refers to a country in order to safeguard national security, protection of human health and safety, protect the environment, prevent fraud and ensure the quality of products on the grounds, take some mandatory or optional technical measures these measures goods and services for other countries to enter the country free market barriers. Numerous and growing number of TBT is having an increasing impact on international trade.

\section{Product Quarantine and Inspection System}

Sanitary and phytosanitary measures refer to animal health and plant health measures to protect human, animal or plant life or health taken. These measures include: measures to protect human life from the food and beverage additives, contaminants, toxins and foreign animal and plant pests incoming hazards; protection of animal life from feed additives, contaminants, toxins and incoming foreign pests measures hazards; protection from foreign pests and plant life measures passed hazards; prevent foreign pests and diseases caused by the measures passed hazards; and the above-mentioned measures related laws, regulations, requirements, standards and procedures.

Statutory inspection of goods and temporary inspection of goods are much important. The products most affected are food and medicine. Foods mainly pesticides, veterinary drugs residues provisions; processing additive provisions; provisions on animal and plant pests and diseases; provisions of other pollutants; production, processing and health and safety provisions.

\section{Packaging and Labeling Requirements}

The negative impact of packaging on the environment caused by packaging waste and packaging is mainly due to the packaging material and container structure formed caused. A lot of packaging waste, especially some reusable waste can not be recycled, the resulting waste has become a major social nuisance. Packaging container structure is irrational, or the safety and health of users would eaters leading to harm, some causes environmental damage.

Over the last decade developed countries have taken measures to develop green packaging, we developed a number of measures to contain clear environmental packaging laws and directives, prohibiting the use of certain packaging materials, packaging waste control pollution of the environment, specifically social parties in the packaging responsibilities and obligations of waste disposal, and many countries proposed packaging waste recycling targets, establish a refund system storage, recycling or reuse of the enforcement of laws to govern packaging waste pollution of the environment, so as to establish a fairly complete green packaging system. In addition to the form of legislation clearly stipulates the responsibility of recycling packaging waste than many countries, the law also provides for the recovery of packaging waste, specific objectives reuse or regeneration. In order to promote the recycling of packaging waste and reused, a group of European design packaging recycling symbolic mark for packers to label the packaging major surface. Include: reusable packaging can be repeated turnover markers; can be recycled (recycling) of packaging 
mark; the use of recycled material over $50 \%$ of the packaging of the mark; the use of green tags. Green packaging measures are being implemented in most countries through a variety of national laws and policies, the implementation of these measures, to some extent, reduce the number of packaging waste and protect the country's environment, but some trade measures on green packaging, then lead to trade friction, impact on international trade.

\section{IT Barriers}

According to goldman sachs statistics, B2B sales in the past few years has been the explosive growth of zero to $\$ 114$ billion today. Deloitte Consulting predicts that by the end of next year US procurement company via the Internet from the current $31 \%$ to $91 \%$ of the total enterprises, and in 2003, B2B sales will be business-to-consumer e-commerce market 6 times. Gold-man Sachs research suggests, $\mathrm{B} 2 \mathrm{~B}$ electronic components and cargo transportation industries will make to reduce costs by more than $20 \%$, the overall cost of doing business is expected to decline $12.5 \%$, petroleum, natural gas and telecommunications $5 \%$ to $15 \%$, paper, chemicals, repair and maintenance services for each $10 \%$, iron and steel, each $11 \%$ aerospace, media and advertising by $10 \%$ to $15 \%$, Life Sciences $12 \%$ to $19 \%$, from $11 \%$ to $20 \%$ a computer, cargo transport by $15 \%$ to $20 \%$, forest $15 \% \sim 25 \%, 22 \%$ metal processing, electronic components $29 \%$ to $39 \%$. Many developed countries have made it clear to enter the e-commerce schedule: United States in 2000, Canada in 2002, the United Kingdom and Germany in 2003, Japan and France in 2004, Italy in 2005. Many industries are also listed schedule: Cars 2001, transportation and warehousing, petrochemical, pharmaceutical and medicine in 2002, paper and office products, consumer products, heavy industry, food and agriculture, construction, industrial equipment and after 2003. In February 2000, General Motors, Ford and Daimler-Chrysler Corporation announced that it will join forces to create the world's largest online virtual market. 3-year company online purchases will reach \$240 billion. This strategic move will force the auto parts manufacturers to enter the B2B field, thereby greatly enhancing the efficiency and labor productivity.

\section{Green Barrier}

Green barriers are those restrictions to protect the environment directly or indirectly taken even ban trade, including international and regional environmental conventions, national environmental regulations and standards, ISO14000 environmental management system and environmental labeling and other voluntary measures, production and processing methods and the environmental cost internalization decile system requirements.

\section{A. International Environmental Conventions}

Currently, transgenic technology and its products (GMO) rapid development in the 21 st century is becoming an important emerging industry, and agriculture, pharmaceuticals, chemicals and environmental protection have a significant impact, in order to solve the food shortage, effective drugs and controlling environmental and other issues shows good prospects. Currently, there are more than 50 kinds of transgenic plant products into commercial production. According to statistics, in 1996 the global biotech acreage body was commercialized 2.8 million hectares, in 1999 amounted to 39.9 million hectares, including United States, Argentina, Canada, Australia and other major producing countries. From 1995 to 1998, GMO crops sales soared from $\$ 075$ million to $\$ 1.5$ billion, up $\$ 2.3$ billion in 1999 , estimated that by 2010 will increase to $\$ 25$ billion. International trade in GMO products is also developing rapidly.

\section{B. National Environmental Regulations, Standards,}

The major developed countries have a number of laws and regulations were developed in pollution control, chemicals and pesticide management, natural resources and animal and plant protection and other aspects of air, noise, electromagnetic waves, waste and other environmental standards for many products. These strict laws, regulations and requirements of the developing countries hampered exports to the markets of developed countries 
In recent years the EU has increased its textile and apparel environmental protection efforts, mainly on restrictions and prohibitions specified hazardous chemicals, textiles all stages of the life cycle, including fiber production, cotton growing and processing, processed products and manufacturing (such as spinning, weaving, printing, dyeing, washing, ironing, sorting), consumer use, etc. have a clear environmental requirements and regulations, such as disabling some of the dyes, organic chlorine carrier, the amount of residual formaldehyde, a preservative, soluble heavy metal residues matter, pesticides (insecticides) and Residues, fabric $\mathrm{pH}$ (PH value), color fastness, special odor (such as musty, foul odor, the smell of fish or other odors), prohibited the use of ozone-depleting substances, inhibit or eliminate a number of harmful bacteria, pollutants emitted in the production process should not exceed the national standards, the other on the human health effects of items (such as clothing wearing comfort, breathability, water absorption, softness, non-irritating, etc.) . In fact, after the elimination of quotas in 2005, green barriers will become Europe's most important alternative quota barriers.

\section{Voluntary Measures}

Environmental labeling could have a positive impact on international trade. Applicable environmental labeling of products and services, and more and more people realize the necessity and urgency of environmental labeling, more and more companies have joined the ranks of environmental labeling. However, due to various countries on the basis of environmental standards, there is the evaluation method such as the use of a lot of difference, which is the development of international trade is unfavorable, the impact on exports from developing countries will be more obvious. In addition, some countries may also be used as a means of trade protectionism.

\section{Conclusion}

In international trade, some countries with technical standards, technical regulations, it is easy to make the implementation of TBT is reasonable nominal, clever sexual references on formal legality, on means of concealment, so that the exporting country hope the sigh, which is embodied in: technical standards, regulations range, so that the exporting country off guard; demanding technical standards, for developing countries is difficult to achieve; some standards through careful design and research, could be devoted to certain countries products technical barriers. Such as the United States in order to prevent potatoes enter the United States, Mexico, the United States provides for standards for potatoes mature head size and other indicators, which gives Mexico planting potatoes to the United States makes it difficult, because you have sold to the United States can not be too ripe harvest, otherwise easily it is broken, so mature and difficult to comply with the requirements needing more research.

\section{REFERENCE}

[1] Xia-You F. Technical International Trade System and Barriers to Trade Freehand figure Style Talk Concept [J]. Economy Hot, 2008, (06).

[2] Yi W. Technological Innovation and Competitiveness of Green International Mechanism [J]. Journal of Anhui University, 1996, (02).

[3] Tao L. Reflections on technical barriers to international trade [J]. Beijing Technology and Business University, 2002, (05).

[4] Wang M. Environmental Regulation and Chinese Industrial Productivity Growth[J]. Chinese Painters, 2001, (04). 